\title{
REVIEWING ENGLISH TEACHING CURRICULUM: COMMUNICATIVE SKILL TO LITERACY SKILL
}

\author{
Rohib Adrianto Sangia*
}

\begin{abstract}
This writing is trying to refresh the memory about Government policy in teaching English of primary and secondary school in Indonesia. The literacy approach is conducted to achieve the effective communicative skills for the students. The literacy has been developed not only read and write but also furthermore in using the knowledge in order to help student role in society. This writing reveals some theory and technique is supporting the literacy approach until in the classroom. It is suggested to the teacher to enrich their capacity in order to preparing the next curriculum so, they can understand and act in the classroom as the literate teacher.
\end{abstract}

Keywords: Literacy, Curriculum, English teaching.

\section{Introduction}

There are many critics and cynical statements that are pointed to the English language teaching both in primary and secondary school in Indonesia that failure in output. Some of the critics and those statements are come from ordinary people, even the education expert. I still remember the night of the opening of my prajabatan training on June 62010 at Balai Diklat Keagamaan Ambon, an officer who is sent from Jakarta in his speech, he commented that the English teaching in madrasah cannot make the student speaks. After all, he contrasted the output of the student in madrasah that studied for 12 years with the students who are finished three-months English language courses that showed the better performance than the madrasah student did. This statements is almost same with the critics from not only from an Adjunct Associate Lecturer in The University of Adelaide South Australia, Subekti (2012), but also from Abbas Badib a professor at Unesa in Media Indonesia (2000), about the failure of English teaching in Indonesian educational system. It means that the implementation of English teaching in Indonesia was failure because the four skills in language, listening, speaking, reading, and writing in high school was not operationable in real life context. Furthermore, Abbas in Media Indonesia (2000) assumed that this failure gave significant loss to the labor and economic of Indonesia because of the uncompetitive high school graduates in business world.

Many significant things could be the indicators in the failure of English language teaching. The first, many graduated students of High School was not well equipped with the language skills, as Putri (2002) and Furchan (2009) examine that all this time, the students seem to be prefer learn about English language itself rather than learning how to communicate by using English, so they produce the knowledge more than the language skills.

\footnotetext{
* Student of Pasca Unesa, Kemenag Class, NIM. 137835102
} 
The second indicators, there are many spreads of English language courses as the indication or maybe it can say as the consequence of the inadequate of the teaching English in regular schools. This issue has been reviewed by Fragozo (2009:112) that, the consequence of the ineffectiveness of the regular school is the on-going transference the role of language teaching to private English course. It means that students, especially to adding his skills in English, the do not have any option but need to see this private English course institution. This reason has made an opportunity for the business of English course. So that, the private English schools are offering something different from regular school, and trying to promote themselves with some slogans, for example, we make English easy(Easy Speak), Others teach you English, we make you speak(English Talk), and the most extremely one is Now Everyone can Learn English with REASONABLE PRICE(Manchester English Course).

These are the reality as the consequence of the ineffectiveness English teaching in regular school. These are the indicators that many regular schools have not given the meaningful teaching to the students in achieving the goal of language as the effective communication. Beside of the reality, basically, English courses is needed by the students, however, it is not focus in developing students skills. For the modern country, especially the country who has English as their first or national language, the goal of English courses usually for some specific purposes, not for the daily English use, whether to academic, business, or in getting certificate of competence such as TOEFL, IELTS, ELP, etc., that is the development after mastering the skills in English language.

The Third indicator that makes teaching English language failure is the implementation of the curriculum by the teacher that sometimes out of tracks. The teachers missed the communicative approach, which is the purpose in English Curriculum in Indonesia. The communicative approach as in Badan Standar Nasional Pendidikan (2006) is including the four language skills, Listening, Speaking, Reading, and Writing. The limitation in applying the material has been done by teacher. The teachers are stuck in teaching skill one by one, without considering the opportunity that is integrated skills offers in the classroom. From this reality, the teachers wasted their time in giving monotonous material that makes meaningful learning cannot be achieved.

Another reason that makes teacher sometimes went out of tracks is the minimum of controls from the supervisor. In reality, schools, especially madrasah in Indonesia, supervisor sometimes, not all the time, is occupied by veteran of the teacher, that still use old paradigms in handling the teachers. The other hand, less of the trainings to the English teachers is one of problems. It makes teacher sometimes felt comfort with this situation and less of inspiration while they are going to teach. After all, Koesoema (2009:74) assumes, some people believe that government did not ready in preparing the teachers in facing the new paradigms, particularly in teaching English language.

The fourth indicator comes from the language assessments from government; Ujian Akhir for Bahasa Inggris did not give any clue about the link between the instructional goals, with the indicators in the evaluation. Fatmawati (2012:8-9) investigated in Surakarta, the final language test to Junior High Schools all around 
Surakarta, it reveals that the assessments focused most in reading, after that followed by writing, there is no speaking nor listening section showed in the assessments instrument. What an ironic situation in language teaching world of Indonesia.

The issues about UAN-fobia itself make the changing of orientation in teaching English in regular school. When we look back about the purpose as explained in English language curriculum by Badan Standar Nasional Pendidikan (2006:126) the first general purpose in learning English to High School students is able to get the communicational competence in spoken or written in achieving informational literacy level, the teacher should present the whole process in achieving the main goal. The main goal according to curriculum is achieving the informational literacy level, but in fact, by ignoring the communicative skills to get communicational competence, the teachers go straight to the informational literacy level, by working, reviewing, and using materials from previous UAN to achieve the better UAN score in the next occasions. The worse thing is English teaching in the last year of the graduation, students is force to deal with many simulations, not simulation in allaying the communicative competence, but simulation in working out the UAN try-out.

From all of the arguments above, the people responses from ordinary to expert about the curriculum on English language, some indicators as synthesized the reality, this paper will trying to answer the question what is the real identity of English language curriculum in Indonesia. As mention above that, the term literacy is use as the goal of Junior and Senior high school. The next part there will be discussed about what literacy-based curriculum is, why it is used, and the implementation of the literacy approach ion the field. After the discussed, hopefully it can open our mind about the essential of the curriculum that the government programed, and become some input in construct our mind-set until instructional design that will be applied in the next time.

\section{Interpretation of literacy as an education policy}

As people know about the history in curriculum development in Indonesia since 2004 is using literacy approach. As Kumalarini and Munir (2006:40) describe that the curriculum 2004 is using literacy approach as the solution in facing the challenging of world and language discourse in the near future. This approach is the forerunner in developing the next curriculum as known as KTSP in 2006. After doing some research and development by government, finally in 2006, KTSP, School based curriculum was launch. It has been pointed out by Wijayati (2011:58) that School based Curriculum is still using literacy approach in order to stimulate and activate the English teaching four skills based. It is also stated in the first of three goals of English Language High School curriculum guideline (Badan Standar Nasional Pendidikan, 2006:126) that the English teaching in Senior High School has aimed in getting informational literacy level. By using literacy approach, the government hoped that this approach could increase the language literacy levels of the students. This program became the fundamental changes in preparing the students in facing the reality in the global society and modernity. Literacy approach in language teaching is a solution to teacher in the classroom that hopefully can maintain the participation the student to use the skills in society. 
Literacy, define by Wray, Medwell, Poulson, and Fox (2002:1) as the whole process in combining two complementary aspect, reading and speaking, which need to developing the students skills with in integrated program in education. In short, cited by Blake and Blake (2002:11), Jack Goody defined literacy as an ability to read as well as write. But by seeing the modernity and globalization recently, Mohanty (2007:64) claims that literacy is beyond reading, writing and numeracy, but it is further in having adequate skills for today's demands. From the last definition, the government of Indonesia was starting the early education for primary school as Calistung as the basic ability that all of Indonesian people need to achieved. At least, the government has started the standard of literacy as able to read, whether in Latin letters or Arabic letters.

\section{Why should literacy approach in curriculum?}

Literacy programs had become an urgent program of United Nation, since the literacy has close connection or relation with poverty. For that, United Nation especially UNESCO proclaimed September 8 every year as International Literacy Day. According to Badan Pusat Statistik (2012:39), the number of adult literacy rate (people that more than 15 years old) on August 2011 is 92,91\%, and ironically it was decreased to 92,81\% in the next year on the same month. This is a fact that the literacy approach in curriculum should be reinforced in getting the better human resources as the assets in succession of the national development programs.

While looking the development of world civilization, and variety that needed by society, the definition of literacy cannot be define as ability to read and write, because it is not relevant anymore, but beyond that, as Mohanty (2007) claimed before. Term literacy is developed, as the world needs changes, not only read and write, but also beyond those are. It is more specific to skills in applying and developing their knowledge from what they read and write in order to give contribution to global society. Kirsch (1993:2) was giving the same perception, as he defined literacy as getting information from printed and written media be a function in society to develops a student knowledge potential in order achieving a student goal. From the definition before, it can be said that, literacy is a step stones learners to develop themselves in answering the real life needs, as the contribution to society. It means the demands for today's need about literate man is not only understanding what he read or write, but ability to apply by make participation in society based on his understanding before.

Literacy can be found in many fields, as we known scientific literacy, mathematical literacy, information and technology literacy, even more the most sophisticated is media literacy. In language teaching, language literacy can be understood as the ability to read as well as write in in novice that can be used as communication media. The communication ability of somebody in a certain level means communicated or understood by people as the contributions. As Kern (2000:2) explained that focus of literacy is from the consideration of reading and writing ability in the social contexts of use, the corridor of reading and writing as complement part of written communication, rather that linguistic distinction or cognitive process. The idea of literacy with second or foreign language teaching after all the current perspective of 
literacy showed the combination between focus on social contexts of language use with additional components that reflected meaning construction and communication negotiation(Kern, 2000:39).

Creating literate generation as the final purpose of education at schools is becoming a need, since the fact that low literacy level has close relationship with the high rate of school drop-out, poverty, and unemployment, which those are the indicators that depict the low value of the human development index of a country(Wagner, 2001:9). The literacy level achievement of a nation reflected the pattern of its society. The developed country inclines the people who have high standard of literacy dan the developing country. If so, it not an excessive expectation to our country for getting a head in the development by extra work in upgrading it standard literacy oh its people.

It is not a new thing if todays, many developing countries is tending to developing their education system with literacy education. This is because the literacy education has purpose to make all the people in the country able to communicate, spoken or written, to fill their daily needs, is schools, business, markets, and all of economic life. Thus, the English teaching as foreign or other language in these counties is focused to developing the ability of language or language skills in order to make the students become autonomous in their whole life, creative, and able to solve the problems with their ability in English language skills.

\section{How is the relation with English curriculum?}

Since competence-based curriculum was run in early 2004, the concept of literacy has been asserted. Literacy, which is a Kern (2000:3) claimed as text-centric in curriculum implementation, is using text as the significant role in the classroom. As we agree that teaching English in school should emphasize the four skills in doing effective communication, the text or discourse is used to be a stimulant to make those skills present. As Kumalarini and Munir (2006:36) explained that from the text, it is expected giving procedural knowledge or implementation of the knowledge not declarative knowledge or only transferring the knowledge. In the school-based curriculum 2006, this principle was still exist, means that it is useful in increasing student literacy in school. Furthermore Kumalarini and Munir (2006) conclude that if somebody has discourse competence, when he involves with a certain discourse, he will connect it with situation and culture around him.

Teaching English with literacy approach giving the meaning that learning English as communication tool, not learning for the language itself. Thus, the use of the language itself can be considered to facing social interaction. It is expected that the student can master the discourse to make them easy in creating a discourse based on his idea in spoken or written. So the job of the teachers is developing student competence in communication or exchanging the meaning(Departemen Pendidikan Nasional, 2004). Finally, English teaching in schools must emphasize in the importance of the using language, which is proper and authentic in order to develop their life skills that able to answering the students need while socializing with the community. 


\section{Literacy and communicative competences}

Language teaching in Indonesia is based on the idea that the goal of language acquisition is communicative competence: the ability to use the language correctly and appropriately to accomplish communication goals. Communicative competence needs supporting component in order to maintain the effective communication. The fundamental competence of communicative competence is linguistic competence is introduce by Chomsky (1965). After that, the competence components for communicative competence was developed by Hymes (1972) with adding sociolinguistic competence beside linguistic competence. The other reformation of communicative competence as introduce by Canale and Swain (1980) by changing linguistic competence to grammatical competence, keeping sociolinguistic competence, and adding strategic competence. Several years later, Canale (1983) revised his previous model of competences by adding discourse competence beside three competences before. Later in the mid 90's Celce-Murcia, Dörnyei, and Thurrell (1995) introduced the model of competences which was combined linguistic competence, strategic competence, sociolinguistic competence, actional competence and discourse competence. Finally, after more than four decades, Celce-Murcia (2007:45) proposed the improvement of the previous model into the figure below to describe the communicative competence to the teachers.

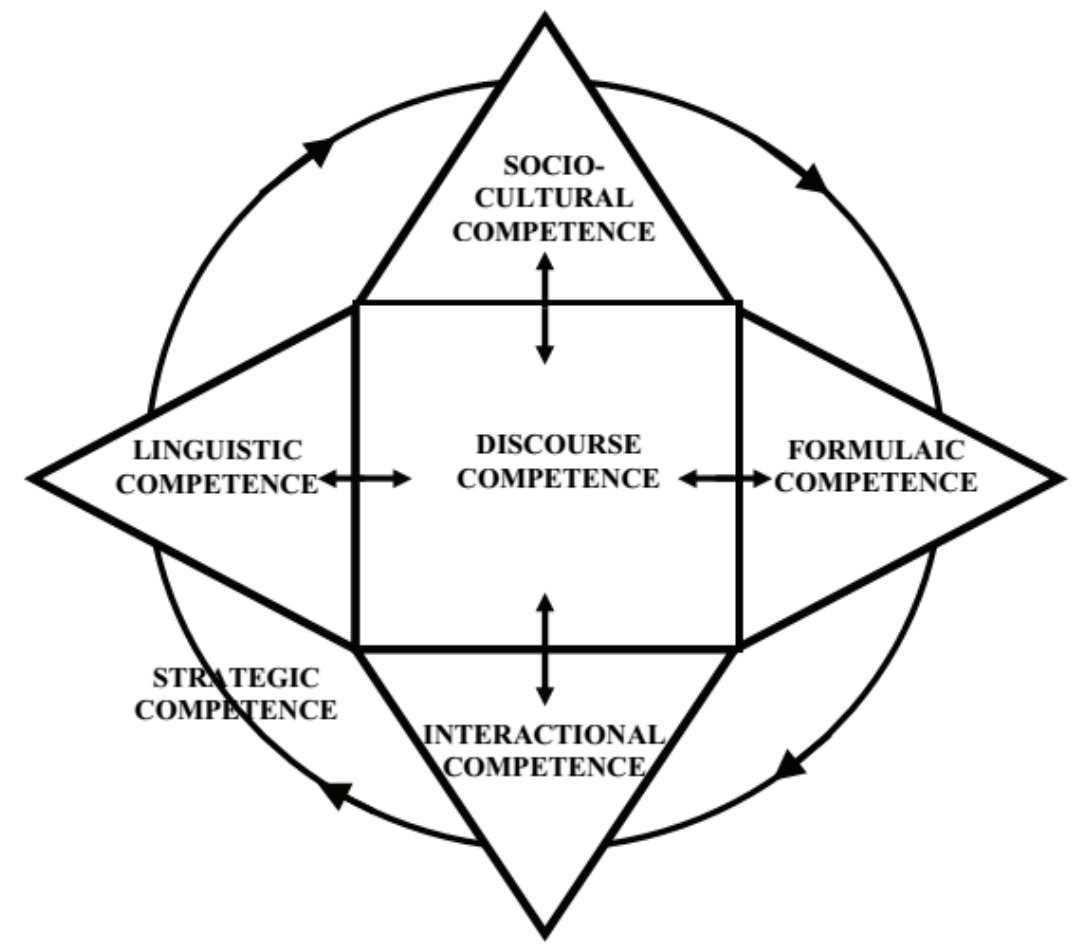

Revised schematic representation of 'communicative competence' (Celce-Murcia, 2007:45)

Sociocultural competence discusses about to the pragmatic knowledge of the speaker, for example, how to express messages properly within the overall social and communication cultural context(Celce-Murcia, 2007:46). Even when good cultural descriptions are available, it is hard to get learners to change their native verbal 
behavior based on a new set of assumptions. Celce-Murcia et al. (1995:23) described several variables of sociocultural which are most essential in terms of the current model. The first, social contextual factors embrace the participants' age, gender, status, social distance and their relations to each other, power and affect. The second, stylistic appropriateness are politeness strategies, a sense of genres and registers. And the third, cultural factors include background knowledge of the target language group, major dialects/regional differences, and cross cultural awareness. These competencies can be acquired in part through some knowledge of the life and traditions as well as knowledge of the history and literature of the target language community.

Discourse competence states to the selection, sequencing, and organizing of words, structures, and utterances to accomplish a joined spoken communication(CelceMurcia, 2007:46). It is the place of the top-down communicative determined and sociocultural knowledge cross with the lexical and grammatical resources to express communications and attitudes and to create coherent texts. There are several sub-areas of discourse competence, four of which are most important with regard to the current model(Celce-Murcia et al., 1995:14). The first, cohesion includes conventions regarding use of reference (anaphora/cataphora), substitution/ ellipsis, conjunction, and lexical chains. The second, deixis contains situational grounding achieved through use of personal pronouns, spatial terms (here/there; this/that), temporal terms (now/then; before/after), and textual reference. The third, coherence, includes expressing purpose/intent through appropriate content schemata, managing old and new information, maintaining temporal continuity and other organizational schemata through conventionally recognized means. The fourth, generic structure means formal schemata that allow the user to identify an oral discourse segment as a conversation, narrative, interview, service encounter, report, lecture, sermon, etc.

Linguistic competence entails the recursive, open-ended systems, which they are phonological, lexical, morphological, and syntactic knowledge(Celce-Murcia, 2007:47). Phonological knowledge includes both segmental (vowels, consonants, syllable types) and suprasegmental (prominence/stress, intonation, and rhythm). Lexical knowledge is the knowledge of both content words (nouns, verbs, adjectives) and function words (pronouns, determiners, prepositions, verbal auxiliaries, etc.). Morphological knowledge includes parts of speech, grammatical inflections, and productive derivational processes. Syntactic knowledge which are constituent/phrase structure, word order (both canonical and marked), basic sentence types, modification, coordination, subordination, embedding.

Formulaic competence denotes to those fixed and assembled pieces of language that speakers use deeply in daily communications(Celce-Murcia, 2007:47). Formulaic competence brought general attention to routines, collocations, idioms, and lexical frames.

The hands-on component of interactional competence is the bottom-up counterpart to the more global top-down socio-cultural competence(Celce-Murcia, 2007:48). Interactional competence has three sub-components that are applicable. The first, actional competence is the knowledge of how to perform common speech acts and 
speech act sets in the target language involving interactions such as information exchanges, interpersonal exchanges, expression of opinions and feelings, problems (complaining, blaming, regretting, apologizing, etc.), future scenarios (hopes, goals, promises, predictions, etc.). The second, conversational competence includes the turntaking system in conversation. The third, non-verbal/ paralinguistic competence includes kinesics (body language), proxemics (use of space by interlocutors), haptic behavior (touching), and non-linguistic utterances with interactional import.

Strategic competence means such behaviors are either learning strategies or communication strategies(Celce-Murcia, 2007:50). The crucial strategies, which are the ones we highlighted in Celce-Murcia et al. (1995:26-29), are communication strategies, they are achievement (strategies of approximation, circumlocution, code-switching, miming, etc.), stalling or time gaining (using phrases like Where was I? etc.), selfmonitoring (using phrases that allow for self-repair like I mean), interacting (appeals for help/clarification, that involve meaning negotiation, or that involve comprehension and confirmation checks, etc.) social (involves seeking out native speakers to practice with, actively looking for opportunities to use the target language).

The explanation of communicative competence of the model above has given some description that what our curriculum have done. It not easy to applied in the real world, but at least, the government effort in giving the better education. The part, will be discussed the suggest procedure in this model submission.

\section{Implementation literacy-based approach in English teaching}

In application of English teaching literacy-based approach, there are four stages or levels of literacy skills. These four levels was proposed by Wells (1987) cited by Finn (2009:124), they are performative level, functional level, informational level, and Epistemic level. The first level is performative level means read and write in the simple way in informal meeting and writing. This skill is expected to the elementary school (SD) in Indonesia according to English language curriculum for KTSP. The next level is functional level, refers to the ability in the purposes of reading and writing demand in daily life and for ordinary community. For example, reading Jakarta Post, filling the registration form, understanding sign, direction or a procedure in doing something. The functional level is expected literacy level to the junior high students (SMP). The third level is, informational level, referred from the ability in read and engage the kind of knowledge that related with the school activity and write certain report or summary based on such knowledge. Informational level was expected to be hold by Senior High Students (SMA), based on the curriculum purposed. The epistemic level, or powerful literacy involved creativity and reason, include ability in evaluate, analyze, and synthesize while reading and writing to persuade and negotiate trough writing and speaking. This level is expected to the scholar people, especially in the campus life. This is the literacy of the people who is conscious with power and self interest in controlling and understanding society where negotiable is occur through language.

After the idea of the literacy level above, we need to understand that literacybased curriculum is conducted from oral cycle (in elementary school) until written cycle 
(in senior high school). It means that the communicative skill in oral cycle is the condition to achieved better communicative skills in written cycle. Even though teaching English is emphasizing in oral communication, the students is introduced with written communication gradually particularly in written language. The explanation gives the understanding ideally that Junior high school students should better in oral cycle, especially to academic purposes in order to supporting their written skills in Senior high school.

For the language teaching in curriculum 2004, Departemen Pendidikan Nasional (2004) recommended learning method as four steps two cycle, which is purposed by Hammond, Burns, Joyce, Brosnan, and Gerot (1992). This model is developed to create the learning better experience of the students start the oral cycle to written cycle. In brief the model can be describe below.

\begin{tabular}{|c|c|c|}
\hline & Oral Cycle & Written Cycle \\
\hline $\begin{array}{l}\text { Building } \\
\text { knowledge of Field } \\
\text { (BKOF) }\end{array}$ & $\begin{array}{l}\text { Sharing Knowledge, Vocabulary } \\
\text { Building, and Grammar Focus. }\end{array}$ & $\begin{array}{l}\text { Sharing Knowledge, Vocabulary } \\
\text { building, and Grammar focus. }\end{array}$ \\
\hline $\begin{array}{l}\text { Modeling of Text } \\
\text { (MOT) }\end{array}$ & $\begin{array}{l}\text { Story Telling and Transactional } \\
\text { and Interpersonal exchange }\end{array}$ & $\begin{array}{l}\text { Reading for comprehension and } \\
\text { interpretation, Reflecting on text, } \\
\text { Reflecting on information } \\
\text { organization, and Reading short } \\
\text { functional text. }\end{array}$ \\
\hline $\begin{array}{l}\text { Joint Construction } \\
\text { (JC) }\end{array}$ & $\begin{array}{l}\text { Constructing Stories, } \\
\text { Constructing transactional } \\
\text { exchange, and Constructing } \\
\text { interpersonal exchange }\end{array}$ & $\begin{array}{l}\text { Planing Text outline in } \\
\text { constructing short functional } \\
\text { text. }\end{array}$ \\
\hline $\begin{array}{l}\text { Independent } \\
\text { Construction (IC) }\end{array}$ & $\begin{array}{l}\text { Constructing performing } \\
\text { stories, Performing } \\
\text { transactional exchange, and } \\
\text { Performing interpersonal } \\
\text { exchange. }\end{array}$ & $\begin{array}{l}\text { Constructing short functional } \\
\text { text, }\end{array}$ \\
\hline
\end{tabular}

Compiled from Kumalarini and Munir (2006:41)

These kind of models discussed above was introduce to Curriculum 2004 (KBK). In the field, many teachers still used this model in KTSP curriculum. Basically, KBK and KTSP are the same in essential and practice because they were focused in language competence. Many text books based on KTSP gave the classified activity and direction to the teacher and student in the frame of four steps two cycle i.e. Look Ahead published by Erlangga. Hopefully this review can make the reader has general understanding with literacy-based curriculum that had been applied, and as the consideration in preparing ourselves in application of Curriculum 2013 that has just launched by the Government. 


\section{Conclusion}

Teaching English has been challenged since the critics of the people about the school output in not like their expected. The government has done their job with making strategic policies in order to increase or literacy levels as the indicator of human development index. Since the definition of literacy has been developed from read and write to the ability in solving the problem with the skills that they achieved in the school.

The increasing of the literacy is pursued by government to make the better future of the students. Literacy approach has been inserted in curriculum with the hope that students to activate the other skills of student so they can explore and develop what they have absorb to become a useful person in the society system.

Communicative competence as stepping stones in reaching literacy skills to the students has been passed an evolution. The development of the communicative competence is the consequence of the development of human civilization on earth. The up-dated model of communicative competence presented in this paper can help a comparable determination for teachers who are increasing their pedagogy skills.

After all, the model of four steps two cycles, which is introduced in earlier 2004 by government, seemed to be better method in English teaching since it is used by the text books, as the representation teacher demands. The capacity of the teacher should be enhanced to reach the national goal in persuading the better human development index of Indonesia

\section{References}

Badan Pusat Statistik. 2012. Perkembangan beberapa indikator utama sosial-ekonomi Indonesia, Agustus 2012. Jakarta: Badan Pusat Statistik.

Badan Standar Nasional Pendidikan. 2006. Standar Isi Untuk Satuan Pendidikan Dasar dan Menengah : Standar Kompetensi dan Kompetensi Dasar SMA/MA. Jakarta: Badan Standar Nasional Pendidikan.

Blake, Brett Elizabeth, and Blake, Robert W. 2002. Literacy and learning : a reference handbook. Santa Barbara, Calif. ; Oxford: ABC-CLIO.

Canale, Michael. 1983. From communicative competence to communicative language pedagogy. In J. C. Richards \& R. W. Schmidt (Eds.), Language and communication (pp. 2-27). London: Longman.

Canale, Michael, and Swain, Merrill. 1980. Theoretical bases of communicative approaches to second language teaching and testing. Applied linguistics Vol. 1 No. 1, 1-47.

Celce-Murcia, Marianne. 2007. Rethinking the Role of Communicative Competence in Language Teaching. In E. Soler \& M. P. Jordà (Eds.), Intercultural Language Use and Language Learning (pp. 41-57): Springer Netherlands.

Celce-Murcia, Marianne, Dörnyei, Zoltán, and Thurrell, Sarah. 1995. Communicative competence: A pedagogically motivated model with content specifications. Issues in Applied linguistics Vol. 6 No. 2, 5-35. 
Chomsky, Noam. 1965. Aspects of the theory of syntax. Cambridge,: M.I.T. Press.

Departemen Pendidikan Nasional. 2004. Landasan Filosofis Teoretis Pendidikan Bahasa Inggris. Jakarta: Direktorat Jenderal Pendidikan Dasar dan Menengah, Direktorat Pendidikan Lanjutan Pertama.

Fatmawati, Rini. 2012. Relevansi Antara Tes Akhir dan Tujuan Pengajaran Bahasa Inggris di SMP Se-Surakarta. No.

Finn, Patrick J. 2009. Literacy with an attitude : educating working-class children in their own self-interest (2nd ed.). Albany: State University of New York Press.

Fragozo, Carina Silva. 2009. English as an international language: a study of the case of Brazil. TEACHING TODAY, TOUCHING TOMORROW No., 105.

Furchan, Arief. (2009). Pembelajaran Bahasa Inggris di Lembaga Pendidikan Islam di Milenium III. Retrieved February 17, 2014, from http://www.pendidikanislam.net/index.php/makalah/41-makalahtertulis/265-pembelajaran-bahasa-inggris-bernyansa-islam-memasukimillenium-iii

Hammond, J, Burns, A, Joyce, H, Brosnan, D, and Gerot, L. 1992. English for Social Purposes: A Handbook for Teachers of Adult Literacy. Sydney: NCELTR.

Hymes, Dell. 1972. On communicative competence In J. P. Pride \& J. Holmes (Eds.), Sociolinguistics: Selected readings (pp. 269-293). Harmondsworth: Penguin.

Kern, Richard. 2000. Literacy and language teaching. Oxford: Oxford University Press.

Kirsch, Irwin S. 1993. Adult Literacy in America: A First Look at the Results of the National Adult Literacy Survey: ERIC.

Koesoema, Doni. 2009. Pendidik karakter di zaman keblinger: mengembangkan visi guru sebagai pelaku perubahan dan pendidik karakter. No.

Kumalarini, Th, and Munir, A. 2006. Pemahaman Guru Terhadap Kurikulum 2004 Mata Pelajaran Bahasa Inggris Di SMP Negeri Se-Kota Surabaya. Pendidikan Dasar Vol. 7 No. 1.

Media Indonesia. (2000). Pengajaran Bahasa Inggris Gagal Total. Nov 5, 2000. Retrieved February 17, 2014, from http://www.library.ohiou.edu/indopubs/2000/11/05/0037.html

Mohanty, Sunil Behari. 2007. Lifelong and adult education. New Delhi: A.P.H. Publishing Corporation.

Putri, Diba Artsiyanti Ediyana. (2002). Bagaimana Meningkatkan Mutu Hasil Pelajaran Bahasa Inggris di Sekolah. Retrieved February 17, 2014, from http://researchengines.com/artsiyanti.html

Subekti, Nanang Bagus. (2012). Mengapa Pelajaran Bahasa Inggris Kita Gagal. Retrieved February 17, 2014, from http://subekti.com/2012/01/03/mengapapelajaran-bahasa-inggris-kita-gagal

Wagner, Daniel A. Unesco International Consultative Forum on Education for All Education for All Assessment World Education Forum. 2001. Literacy and adult education. Paris, France: UNESCO.

Wells, Gordon. 1987. Apprenticeship in literacy. Interchange Vol. 18 No. 1-2, 109-123. doi: 10.1007/BF01807064

Wijayati, Maria Goreti Istty. 2011. Case Study Implementation of School Based Curriculum (KTSP) by the English Teacher of SMA Negeri 2 Wonogiri. Humaniora-eJournal Fakultas Bahasa Vol. 3 No. 3.

Wray, David, Medwell, Jane, Poulson, Louise, and Fox, Richard. 2002. Teaching literacy effectively in the primary school. London: Routledge/Falmer. 